\title{
Social Problems in
} the Russian Army within the Framework of Social Work

Irina Surkova, Associate Professor, Department of Social Anthropology, Saratov State Technical University, Russia

E-mail: irina_surkova@mail.ru 


\begin{abstract}
:
This article aims at describing social problems we find in the Russian Army. The research has allowed us to get a ranging of servicemen's social problems: housing, material maintenance and hard-earned money, realization of social guarantees, life conditions and problem of relationships within families, time-limit, the regulation of life, restricting the freedom, humiliating treatment of juniors and bullying. Unsolved social problems of servicemen may also cause that people who are going to protect the country from danger, may become threats themselves. The Russian army consumes a great amount of resources. Recently mass media has put these issues on the public agenda. Focus in article is also to give a picture of how social workers work to solve social problems in the Russian Army.
\end{abstract}

\title{
Introduction
}

For many centuries the Russian Army has been associated with great victories and at the same time with great sorrows and troubles; not only because of tragedies and human losses but also because of very hard conditions soldiers encounter during everyday training.

Problems associated with military service in Russia are of national importance nowadays because the Army is an integral part of the State. In view of transition to market economy such problems increase the number and complexity of social issues.

Federal laws and local regulations that are supposed to guarantee effective program of social support to regular servicemen contradict one another and intensify social tension in the environment of these people. Their integration into military social space is very difficult. The system of social support to servicemen is of fragmentary character in relation to their way of life because stated privileges and guarantees for people serving in the army are not being provided. As the result it becomes important to carry out social research that will give information about problems of servicemen and help to communicate with organizations involved in implementing social policy within the military sphere.

Herein the author would like to present and discuss issues concerning present situation in the Russian army, social issues and problems that the army has to deal with as a social institution, life experience of servicemen and a much smaller number of servicewomen. Social problems within the society that are related to current position of servicemen, military and defence policies of the Russian Federation will also be looked upon.

\section{Theoretical approach and background knowledge}

Unsolved social problems of servicemen can generate anomie in the Armed forces of the Russian Federation. Dissatisfaction with social status may provoke mutiny. As the result people who must protect the country from danger may become threat themselves.

The traditional concept of security protects interests only of the state and government not paying enough attention to the interests of «individuals and groups ethnicities, religious groupings, political and ideological groups and non-state actors» (Muthein 2000). Scholars representing the concept of «human security» oppose the concept of «traditional national security» and support the idea of protection against all forms of violence, articulating principles of freedom, respect of honour and self-respect. «Positive or stable world structure» that consists of public groups and institutes is necessary for maintaining security (Moller 2000:2). It's obviously that provision of internal order in the army is of great value for solving problems of national security. In turn this order builds upon proper social provision of servicemen. Within this context it's very important to analyze social problems of servicemen in the Russian Army and approaches to solving such problems. 
Principles of equality and brotherhood used to dominate in the Soviet state. In fact it was only declaration: there still remained inequality between people and society. There existed social stratification based on hierarchical ranging of all the members of society. Any social group had its own stratification. It should be noted that there was an opportunity of transition from one social position to another. The army was the first channel of «social mobility» (Sorokin 1992:393). It played a great role during wars when protection of the state was highly valued by society (Sorokin 1992:394). The army became «the lift of social mobility» - there were heavy casualties among officers due to military operations. As the result these emerged vacant positions that were taken by people of lower social status.

In peace-time the value of Armed forces as a mechanism of climbing up «the social ladder» becomes less obvious. The raising of your position within stratification pyramid, the more material, social and cultural resources you possess. The personal attitude to military service mostly depends on material living conditions and on the level of social protection guaranteed by the state.

Recently much discussion in mass media has been given to the great amount of resources consumed by the army. However, the saying «those who don't want to feed their own army will feed another's» is still up-to-date in view of turbulent situation on international scene, local conflicts that flash across the Russian territory and danger of international terrorism. Social problems of servicemen and approaches to their solution are directly connected with privileges and guarantees that are provided for this category of citizens.

The state's social policy concerning servicemen and citizens dismissed from military service should have a number of various material and non-material stimuli for adequate compensation of the rights partly or completely alienated from servicemen, spent time and efforts characteristic to their trade. Military social worker should be responsible for covering all these issues and at large become the main actor of the state's social policy.

\section{Brief of the military social work}

Practical social work within the military sphere has long-standing tradition, rich history and the first it was deployed in the War between the States (1861-1865) under the Sanitary commission of the USA (McNelis 1993:118). The primary goal was to return the hospitalized soldiers inside the army formation. However professional social workers have been working with the U.S. military since World War I (Daley 1999) when the first psychiatric training for social workers has been organized (McNelis 1993:18). The profession as we know it today was first recognized in November 1943, when the Army designated psychiatric social work as a separate job category (called a "specialty code") and appointed the first social work consultant to the Surgeon General of the Army (Garber \& McNeilis 1995). In the end of The Second World War about 711 social workers were on active duty in the army as soldiers or sergeants (McNelis 1993:18). The officer rank for social worker has been appropriated for the first time in January, 1946 (McNelis 1993:18).

The United States Air Force has 225 civilian social workers and 215 commissioned social work officers (Tarpley 1999). The Unites States Navy employs 400 civilian social workers and 31 commissioned social work officers (Kennedy 1999). Excluding civilian social workers employed by the U. S. Army this represents over 1,000 social workers (Tallant \& Ryberg 2000) It is important to note that because military social workers are part of the medical branch of military service, they are technically considered noncombatants, meaning they do not engage in the actual fighting (Simmons \& Rycraft 2010:10) However, military social workers regularly deploy to combat areas, where they provide mental health prevention and treatment services to the soldiers, sailors, airmen, and marines who are fighting a war and often need them for support (Simmons \& Rycraft 2010:10). 
The literature analysis has shown that there is a number of the publications devoted to ethical problems which military social workers solve in there donkey service, emergency situation and war. (Simmons \& DeCoster 2007; Simmons \& Rycraft 2010; Flynn \& Hassan 2010; Daley 2003). It shows popularity of social work in military formations of the USA.

In Russia the history of professional social work has rather succinct history and it has begun since 1995. The formation of modern social work has influenced the Soviet past. Social policy in the soviet period has been mediated by a «high role of the state in various sectors of public life, and also socialist principles of economy and culture management» (Romanov \& Gatvinski 2003:43). Now the ideology of social security changes, being guided by model of "the address social help" (Yarskaia 2003:14). It based on activization of human resources and on principles of partner relations between the state and the client. Thus, there is a transition from welfare to workfare (Grigorieva 2003:43).

However many servicemen don't know about such post as social worker. Functions of social workers are executed by the second-in-command of character building (Surkova 2006:141). In this connection it is almost impossible to present data about the military and civil social workers serving in the Russian army. Naturally, there are differences between social work "medical approach" used in the USA and social work in Russia. Firstly, in Russia social work is connected with remedial activity from various forms of discrimination, acting as the mechanism of realization of social policy in Armed forces, and as the realization mechanism socially-legal protection servicemen (Lipsky 1998). It corroborates a post full name - the officer of social work and preventive maintenance of offenses of a regiment. Secondly, considering that duties of social work are shifted on officers of character building, there is a stereotype that social work is the pedagogical activity directed on preventive maintenance of offenses. All approaches set forth above ignore one of the most important problems of social workers - the help in the solution of social problems.

\section{Methodological approach and data collection}

Quantitative and qualitative design of this project employs different methods to illustrate research issues. Quantitative data will enable to accumulate statistical information on a number of problems in the army; however such data cannot represent subjective experience of respondents. Qualitative design of this research will illustrate individual experience but will not show how social protection of servicemen as a social group changes with time. Thus, combination of qualitative and quantitative data will be used to reveal a number of problems in the Russian army. Reliable data on daily hardships in the army were collected from literature, statistics, records of interviews with servicemen and the distribution tables of answers given by servicemen in the questionnaires.

The main purpose of this project is to analyze the system of servicemen social protection within the social work context. The basic emphasis focused on the following research questions:

\section{What are the main social problems of servicemen in the Russian army?}

2. What are the main directions of the state's social policy that help to raise social status of servicemen?

\section{What are the directions of military social worker activities today?}

Research was carried out at the territory of military units. Closed structure of the army accounted for the fact that I encountered difficulties in communicating with generals and colonels. It was practically impossible to receive information in the official way. I entered the military unit incognito using informal contacts. At the beginning servicemen felt themselves very uneasy. Later during interviews they started telling me more about their daily hardships. They said that their social status was very low but they were hoping for the change of this situation. 
The research was carried out in the time span of 2006-2007 in one of the military districts of the Russian Federation. I visited 5 military units. The following methods were used in this research:

1. Interviews with servicemen aiming to reveal social problems of the military units ( 12 respondents).

2. Analysis of the regulatory framework in regard to forms and methods of social work.

3. Questioning servicemen in the military district with the purpose to analyze the system of social protection in the army (501 respondents).

The quantitative research based on the cluster sample that presumes primary selection of the groups and then analysis of all elements inside of the clusters (Pechenkin, Bagutskij \& Surkova 2008:11). Such clusters, as schools, hospitals, and in our case military units are used in the analysis of specific populations because servicemen are naturally grouped in military divisions. In our questionnaire cluster was the Institute of improvement of servicemen professional skill in which officers and warrant officer from all regional and regional centers of the Russian Federation were trained within several months. In this organization we planned to do questionnaires with all participants, however as a result many servicemen have refused to answer. As a principal cause of refuse they called secretiveness of their profession and impossibility of dialogue with the researcher about there social problems.

Cluster sample was put at the basis of this questionnaire because manifold of servicemen are grouped within military units and divisions. 501 servicemen took part in the questioning. $90.4 \%$ of them were men and $9.6 \%$ - women. Such percentage of women is explained by insignificant representation of women in the structure of the Russian Armed Forces. At the beginning of 2007 - 95000 women were serving in the Russian army that was $8.5 \%$ of its total number (In the Russian army... 2007).

Respondents were aged from 19 to 58. The average age of respondents was 30.8. The most part of respondents were in the age category of 25 . The number of years served in the army varied from 1 year to 38 years. The average number of years served was 11 years. $77.8 \%$ of respondents had higher education. Categories of military ranks distributed in the following way: common soldier and sergeant $-9.4 \%$ warrant officer $-10.8 \%$; junior command personnel $-21 \%$, middle command personnel $-50.2 \%$; senior officers $-9 \%$.

Within the frame of qualitative methodology we had been spent the semi-structured interviews with 12 servicemen. Selection of respondents was carried out in the military units located in the cities of Moscow, Saratov, Samara by a method of "a snow clod". It is a method to get in touch with members of certain group when one respondent reduces the researcher with other respondent in the same group (Tompson \& Priestley 1998:447). The leitmotif of the research was questions about social problems which servicemen encounter throughout the service and about ways of their solution, including by the activities of the military social worker.

\section{Summary of finding regarding social problems for servicemen in the Russian army}

During interview we reveal a number of problems which excited almost all interrogated servicemen. It has formed the basis for their inclusion in questionnaire structure. On a picture 1 you can see results of questionnaires. 


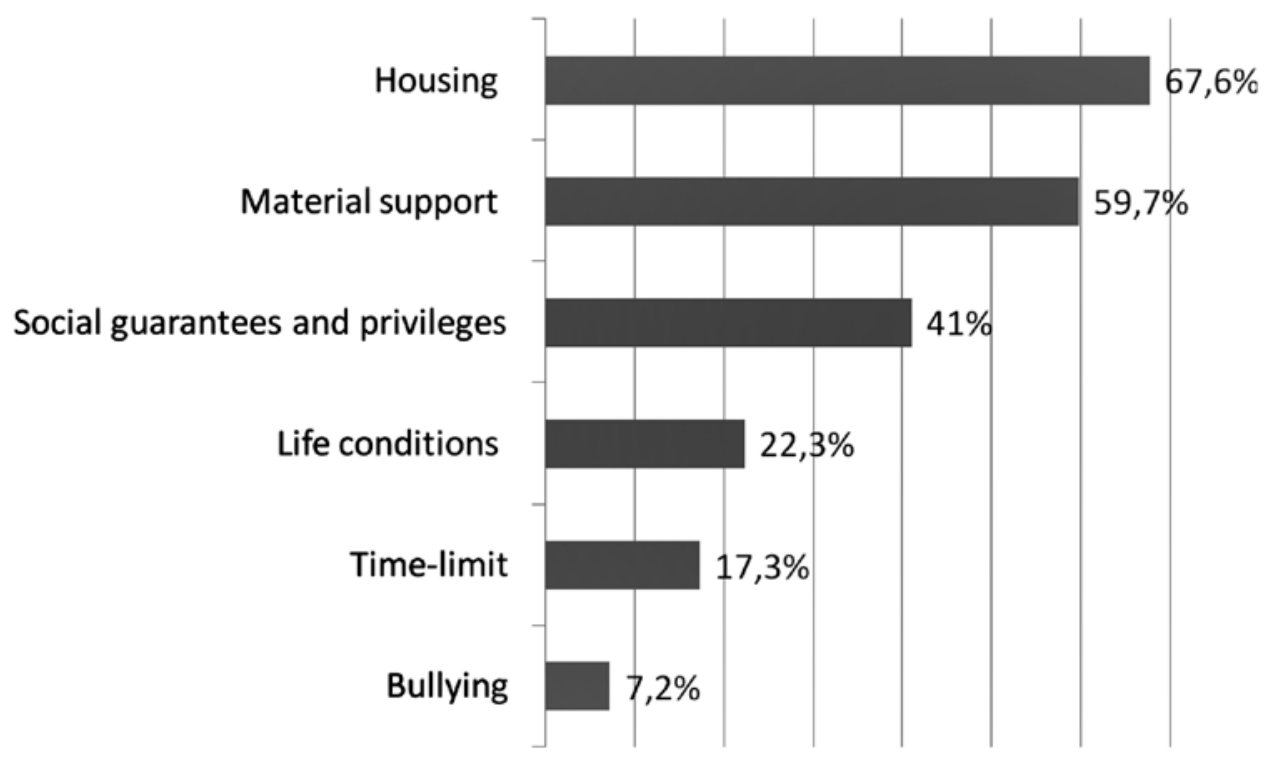

Picture 1: Social problems of servicemen

\section{Housing}

Opportunity to purchase accommodation is of great importance for servicemen. Solving «housing problem» depends on the region in which the serviceman is placed. Free-of-charge housing used to be one of the attractive sides of military service.

The data show that $55.7 \%$ of respondents joined the army hoping to receive housing in the nearest future. More than a third of respondents (41.9\%) live in military units; $20.4 \%$ - rent apartments; 12.6 $\%$ live in their parents' apartments; $10.2 \%$ live in hostels. Only $10.8 \%$ of respondents stated that they had no problems with housing. The majority of servicemen require housing improvement or need apartments. So, Vyacheslav (31 year, warrant officer, total military experience - 14 years) noted,

«I live with my parents and a brother in a three-room apartment with adjacent rooms. I am not on good terms with my relatives. In order to be placed on the waiting list for getting my own apartment from the military unit the total area of our apartment should be 2 square meters less. The total area includes rooms, the kitchen, the corridor and the balcony. If I decide to marry we'll live on my balcony. If I choose to live in a hostel - it will be deterioration of living conditions. Thus I cannot get on the waiting list for another 5 years. It is a vicious circle...».

This statement shows imperfection of regulatory framework in regard to provision of servicemen housing.

Dissatisfaction with housing accounts for a number of negative social phenomena. For example, the majority of servicemen who did not receive housing from the Ministry of Defense suffer serious financial losses because of insufficient amount of indemnification for housing.

«We have not enough money to pay for the apartment. What kind of apartment can we rent for such money? We're getting compensation for commuting and it is not enough for other expenses» (Michael, 35 years, major).

So, for example, if we compare the salary of commander of platoon (lieutenant, military experience - 4 years) and the lowest price of an apartment in the suburb of the capital we shall see that the serviceman will be able to buy it only in 22 years time. In this calculation I am not taking into 
account the inflation, constant growth of prices for accommodation, expenses on food, clothes and living essentials. Unfortunately salary growth in 2006 has not changed this situation.

The right of servicemen to get housing is stated in the Constitution of the Russian Federation (Chapter 2, Article 40). Provided accommodation may include room in the hostel, location at outquarters and other kinds of housing. Provided apartments should be equipped with the things necessary to create normal domestic conditions for staff. The right to housing is detailed in Article 15 of the Federal Law «About the status of servicemen».

One of important direction in solving housing problem for servicemen is financial support for purchasing apartments or houses. The right to receive and use such financial support is confirmed by the state housing certificate (The program started in 1998). Such support is granted to servicemen from the federal budget and amounts to $80 \%$ of the housing cost. The transfer is made directly to the seller's bank account.

The positive side of this program is the opportunity to get apartment in a short period of time. The negative side is the fact that servicemen should have enough money to cover $20 \%$ of the apartment cost. Recalculation of the housing certificate is done once a year but the prices of apartments rise every day. Therefore the certificate cannot guarantee proper housing. As the result the program «State Housing Certificate» is being realized only by $32 \%$ (Mukhin \& Baranov 2003).

Nowadays new directions of solving housing problem are being discussed actively. One of such directions is introducing "accumulation system of buying accommodation". For example, a person who chooses to serve in the military should make a contract with the Military Department for a certain period of time. After that there will be opened an accumulation bank account and every year the state will transfer money to this account for buying accommodation. It is supposed that when the serviceman is dismissed there will be money on his account sufficient for purchasing housing in any area of Russia.

Thus, the task of providing servicemen with housing demands a complex approach, combination of various mechanisms for realizing social policy in this context. Provision with housing is very important and needs to be aimed. The aim grants from the Ministry of Defence must be combined with provision of «housing certificates».

It is necessary to control distribution of money under this Program. Free-of-charge housing for servicemen from the housing fund carried out by federal executive powers is of importance too. Besides, it is necessary to establish interaction between various Military departments in order to optimize distribution of housing among servicemen belonging to different ministries. It is necessary to involve non-budget funds for long-term crediting. Such consolidation of actions and combination of various mechanisms will allow solving habitation problem in the Russian Army.

\section{Life conditions}

The terrible life conditions are a very big problem for servicemen as the same "housing problem". We deliberately unsettle sequence of problems' priority demonstration, because the problem of "life conditions" was selected by $22.3 \%$ of respondents. This problem occupies only 4 point in the list. However the problem of "life conditions" is frequently the basis for "housing problem". Women on this point in question have expressed twice is more critical, than men. If provision of housing means allocation of accommodation then "life conditions" are connected with quality of this flat or house.

So, in one of the military unit the colonel with his family lived in the makeshift barrack reminding "the big shed" with a mould on walls and rats. Experts of the Sanitary \& Epidemiological Service recognized this accommodation condemned building for human habitation. (NYT: servicemen are left... 2009) 
Social unsettled conditions noted by $23.7 \%$ of respondents influences demographic situation among officers as well (according to the data of All-Russian trade union of servicemen half of the families of junior military personnel have no children. $40 \%$ of marriages break up, the number of officers-bachelors has increased more than twofold during the last five years).

The problem of relationships within the families becomes the most important within this context. Earlier wives of servicemen went with their husbands to places of their assignment but now there's another tendency. E.A. Kashchenko believes that the main reason for it is "non-uniformity of socialcultural gender development and increasing sexual pretensions of a serviceman to his partner conditioned by the change of sexual culture within society as a whole" (Kashchenko 2003:88). But some researchers don't give attention on sexual culture of servicemen. They demonstrate other factors, for examples, problems of frequent residence change, extreme circumstances of military life, hard time-limit, and deficit of interaction within the servicemen family (Lugovaya 2004:20-21) In our research respondents bring to notice on social factors too such as existing housing problem and the lack of proper living conditions.

Such point of view is supported by Danila (senior lieutenant, total military experience -2.5 years):

«I didn't get on a waiting list for housing. I do not see the reason why I should do it? I see other families in my hostel. For example, majors live in the hostel for several years. They have children of 6-7 years old. One major and his family live in one room (10 square meters) and they share the kitchen with 20 other people. They have a bathroom for 4 families. These are terrible conditions. Maybe he will be able to buy an apartment in 8-10 years if he gets a housing certificate. I know that I have no chance to get housing from the military unit. My wife didn't come with me to this military unit. She said "What am I going to do there with our kid?"

It testifies that «housing problem» is the factor that destabilizes normal family relationships.

The specifics of military service foresee periodical change in the place of residence. In many cases members of servicemen's families cannot find jobs in their specialities and become unemployed. The amount of salaries paid to servicemen becomes of great importance. Poor financial provision of servicemen influences opportunity to get proper accommodation.

Such situation increases psychological tension between military people and undermines fighting capacity of the Russian army. The government of the Russian Federation is actively seeking ways to solve housing problem and problem of bad life conditions.

\section{Material support}

The second place is occupied with a problem of material support of the servicemen $-59.7 \%$. Disastrous state of the army is marked by "problems of budget assignation, social non-protection of servicemen and their catastrophic material exfoliation" (Army of Russia: Its State and Perspectives 1999:27).

Most families of servicemen and people dismissed from military service are on the edge of misery and «they do not view themselves as middle class» (Peven \& Shishkanov 2002: 90). Expression «hard-earned money» suddenly acquires not only figurative meaning but direct meaning as well because servicemen have to give blood to blood donor centers for extra pay in order to provide their families with proper living conditions. 
It is illustrated by the statement of Sergey (captain, company commander, total military experience -7 years),

"I have a wife and a little son. We have no relatives in this town. My wife does not work because she has to look after our son. Money is absolutely not enough. We found out that it is possible to give blood to blood donor centers for 500 rubles pay. So, this is extra money. I do it twice a month. All people in our hostel have such problems». Ekaterina (warrant officer, total military experience -1.5 years) said, «When we need to buy something, for example, a winter cap for our child my husband and I go to the donor center. Usually he goes there alone but this time I had to go with him to buy winter clothes».

Satisfaction by the level of material support is in many ways determined by the region where service is made. Alexei (captain, company commander, total military experience - 10 years) expressed an interesting point of view on this topic. He noted,

\begin{abstract}
«Speaking about the salary-is it enough or notenough for normal life conditions? We need to make a comparison. My friend is serving in the countryside. So he practically does not spend his salary. Products are cheap. Most people have their own farmsteads. The rent of apartment is very very cheap. And I have to serve in a big city. So I have a lot of payments to make and money is never enough».
\end{abstract}

Let's notice that the level of income was considerably raised during the last few years. In 2003 the average monthly income of each member in the serviceman's family of Saratov was 2559.75 rubles. Whereas minimum living wage in Saratov was 1930 rubles. The income of servicemen was slightly above the living wage. So the monetary allowance of servicemen amounted to $60 \%$ of the minimum living wage (Social Aspects of the Military Reform 2003). Experts called such socialeconomic situation as "poverty".

The results of my research show that the monthly income of each member of a serviceman's family varies from 1000 rubles to 35000 rubles. In average a serviceman receives 8049 rubles which is approximately 2 times higher than the living wage in the Ural region (Sverdlovsk area - 3862 rubles, Tyumen - 3956 rubles) and in Saratov region (3537 rubles). Thus, the income of servicemen increased by 2.3 times compared to 2003.

However during this period prices for food, living essentials and charges for utilities went up high. During the questioning $59.3 \%$ of respondents pointed to low monetary allowance and material supply. Besides, some respondents pointed to difficulties in visiting European countries.

«What kind of salary is that?! ... I tried going to Greece. They asked for my earnings record. My salary has to be more then 12 thousand rubles in order to open the visa. If I want to go with my child my income should not be less than 15 thousand rubles. As the result I couldn't go anywhere in Europe because we are not creditworthy for Europe» (Alexander, 26 years, junior lieutenant).

Statements of the kind were made by other servicemen as well. It is a good sign that servicemen begin thinking about and planning trips abroad. But yet their income is far from European standards and doesn't correspond to material level of middle class.

\title{
Social guarantees and privileges
}

Guarantees are the duties taken by the state up on creation of necessary conditions and maintenance for realization all elements of the social status of the servicemen, the military pensioner, and members of their families. There are (The Federal Law №76): advance payment of 
dislocation allowance to dependents (article 13 item 3); payment for essential acquisition (article 13 item 7); maintenance with the foodstuffs, ware property or monetary indemnification instead of subjects of ware property (article 14 item 2); accommodation and reimbursement for renting (article 15); health protection and medical aid, sanatorium treatment and payment of health resort voucher cost for school-aged kids (article 16); obligatory state personal insurance at the expense of means of the federal budget (article 18); journey of the serviceman and members of his family on a gratuitous basis in the established cases and free conveyance (article 20); additional social guarantees and indemnifications given by the serviceman, fulfilling duties of military service in the conditions of state of emergency and at confrontations (article 25).

The ranging of problems of respondents showed that the third place (after housing problem and insufficient monetary allowance) is occupied by inadequate provision with social guarantees. Such point of view was supported by $41 \%$ of respondents. One of the respondents noted,

«Now everybody says that all privileges are replaced by monetary equivalent. They say it is targeted support. For some people privileges are not so important. As the result of this law I lost about two thousand rubles because now I have to pay for my apartment and municipal services entirely and it is practically one third of my salary. Who has won from such law I ask? My life became worse» (Michael, 50 years, lieutenant colonel).

All interviews proved such opinion.

Thus, reforming the system of social privileges and guarantees is another aspect of social protection for servicemen as a part of measures for realizing social policy in the army. Accordingly it is necessary to improve the regulatory framework in regard to social protection of servicemen, privileges in taxation within the context of «targeted support» to this category of people.

Sergey (major, senior assistant of the chief of the special military department) has an interesting idea, "Certainly there are problems with privileges for servicemen but this is not a matter for discussion. By the way nobody has died of it; nobody ran away or tried to leave the army. In fact there are privileges for a number of years in the service and a possibility to retire earlier. A serviceman knows that he will be receiving a good permanent pension».

This statement testifies that some rights and guarantees are infringed. But these problems are not as significant as material allowance or provision of housing to servicemen. Besides, the state executes social guarantees, but telling the truth it is not always that volume as it is registered in the legislation.

Unresolved social problems revealed that $40.5 \%$ of respondents are not satisfied with conditions of work and $11 \%$ of respondents do not wish to make a contract for continuing military service. Ranging of the reasons for dissatisfaction with service in the army revealed that the leading place is occupied by non-observance of the schedule of work $-55.8 \%$. Practically all respondents who marked this position were men $-96.2 \%$. Some interviews illustrate this point of view.

"I want to say about women in the army. I couldn't understand why women are needed in the military? She is recruited... then her child gets ill or she needs to be at home at five o'clock. And we have to work above our heads... Anyway women practically are not called for work; basically the entire load goes on men» (Alexei, 35 years, major).

This point of view shows that the problem of non-observing the mode of work and rest concerns mostly men; servicemen have gender stereotypes to women in the army; chiefs are more permissive in relation to women. 
$20 \%$ of respondents noted a big load of work. Respondents say that the work is very hard and is accompanied by stressful situations. The salary does not correspond to the level of physical and mental efforts made by servicemen. Besides, $11.6 \%$ of respondents pointed to bad terms with their chiefs. Even such statements were present, «l am worried about indifference of commanders to the problems of servicemen». $4.2 \%$ of respondents are worried about bad relationships with their colleagues.

These problems can be solved by military social workers because they possess necessary knowledge, useful methods and enough authorities to change the situation.

\section{Time-limit}

The following block of the servicemen problems is based on the specificity of military service in the Russian Federation. So, the problem of very rigid regulation of time-limit freedom mentions $17.3 \%$ of respondent servicemen.

The majority of the respondents experiencing difficulties on this point in question, is a common soldier, sergeant and junior command personnel. Important comment that now in Russia there is a general liability for military service. But about $80 \%$ of recruits go on military service without desire (Serebryannikov 2002:85). As the result there is «a violent reduction of the person» (Bannikov 2002:25) when the person can't operate voluntarily any more and to the discretion. He gets to the closed space where there is a change of all social practice of the subject where the person loses the social body and social space. The basic loading on work with a combat-fit manpower comes upon on junior command personnel. Their daily loading repeatedly increases because of avoiding of various incidents.

So, Alexander (26 years, junior lieutenant) noted «When I has come after institute to the military unit so I has lodged here. Certainly, it is very difficult, when almost constantly you are in territory, all under the schedule. Differently it is impossible, it is necessary to supervise for soldiers constantly, indeed all they want home, can escape, get drunk, moreover something is more terrible for making. And I will be guilty».

Space restriction - life in military unit territory, in territory of barracks premises, and also a timelimit - life distribution on hours and minutes - is serious test not only for soldiers, but also for their commanders.

\section{Bullying}

Humiliating treatment of juniors it is defined as the power of old file over new recruits. The certain rights and duties are fixed to each socially-age class. The age in this system has high level of rituallysymbolical registration (Bannikov 2002:25). The informal etiquette orders all servicemen various behaviour; however this behaviour often carries delinquent character. It can lead to traumas and even destruction of soldiers - recruits.

According to the information from Mother's Right public foundation, about 3,000 servicemen die in the Russian army every year. "The statistics of the Defense Ministry is not trustworthy. Military officials say that 1,100 young men died during their army service in 2004. In 2005 3,000 Russian recruits died of army hazing (3,000 Russian recruits... 2005). Veronica Marchenko has paid attention that "We have recently had an absolutely outstanding incident, when parents received a call from a military unit. They were told that their son jumped out of a window after he decorated a Christmas tree. Other parents were told that their son committed suicide because he was reading Chekhov" $(3,000$ Russian recruits... 2005). Such facts are possible to explain that command of military units 
try disguising facts of the humiliating treatment of juniors in territory subordinated to them. It can be testified in our questionnaire when a problem of bullying as the priority has chosen only $7.2 \%$ of respondents. It practically coincides with representation in questionnaire of the common soldier and sergeant category.

\section{Role of social workers in solving social problems of servicemen}

In the present research I tried to define social problems of the Russian Army. In my opinion military social worker can help to solve such problems.

Military social work is the system of legal, political, economical, educational, social and other activities realized to guarantee proper material provision of life and privileges for servicemen, citizens who were dismissed from military service and members of their families, civil personnel in the Armed Forces. The main purpose of military social work is to create normal social conditions in which servicemen and civil personnel can effectively fulfill duties assigned to them.

Social work in the army has very rich and diverse history. Social workers must provide direct services focusing on such issues as family violence, substantial (alcohol and drugs) abuse, mental illness, adaptation to military service, wartime trauma, coping with physical illness and health enhancement. (Daley 2003:438)

The main tasks of military social work in the Armed forces are (Luk'yanec etc. 2005:235-236): creating recommendations and proposals aiming to solve social problems of the military organization for further development of the regulatory framework; studying and forecasting social conditions in the military environment and within military units; providing legal education to servicemen; training of commanders and other officials on the legal basis of social protection of their subordinates; analyzing condition of military discipline in military units and developing recommendations to strengthen it; coordinating activities on realizing rights and privileges of servicemen; coordinating activities and establishing partnerships with the government and local non-governmental bodies to solve the problems of servicemen; providing social guarantees to servicemen, citizens who were dismissed from military service, members of their families and civil personnel of the Armed Forces.

In July, 1995 within the structure of the Armed Forces of the Russian Federation there was introduced a new job position - military social worker. He is an officer for social work and prevention of violation in military units (Order of Minister of Defense 1995).

Faculty of military social work was opened on February 3, 1996 at the Military University of the Ministry of Defense of the Russian Federation. The program of this faculty covers 5 years. Graduates receive qualification «social worker» and a primary military rank "lieutenant".

Unfortunately, military social work in the Russian Army is underdeveloped. Soldiers, families of servicemen, people who were dismissed from the military service do not know about the activities of military social worker in military units.

According to our research $51.9 \%$ of the respondents have noticed that the social worker post isn't present in their military unit, whether and $11.9 \%$ have found it difficult to define the given expert works in their military unit.

Such job position exists only on paper. Servicemen take the duties of social workers without having special education and enough knowledge for it. Such situation helps them in further promotion. One of such social workers said, 
"I've been serving in this military unit for several years. I know all its traditions and laws in the army better than other people. So I don't need any special training to be a psychologist or social worker. I can understand soldiers well enough..." (Oleg, captain, total military experience -5 years).

This opinion is not quite right because he can use only his life experience. Such military social workers are unable to use methods and techniques to work with soldiers and other military people. This is what professional military social workers should do.

The main function of military social worker is to carry out activities of targeted social support to servicemen and to improve tolerant gender relationship. $53.1 \%$ of respondents noted that they had no military psychologist in their organization and $5.6 \%$ of respondents didn't know how to answer this question. It means they didn't know that they could receive psychological help in the military organization. Research shows the same situation with the position of military social workers. Only $36.3 \%$ respondents noted that there was such a specialist in their organization.

Training quality of such specialists is a very important issue. The results of interviews show that most part of military psychologists and military social workers are servicemen who want to get captain position for further promotion.

"Yes, we have a military social worker but he is a former commander of the second company. He is eager to study at the academy so he took this position. I wouldn't want to discuss my problems with him. How would he help me?» (Sergey, 31 years, captain).

Similar statements testify that the position of military psychologists and military social workers are occupied by people who do not have special psychological or social education. They cannot provide qualified help to build optimal psychological climate within the units or to solve conflict situations with the chiefs. Moreover, these specialists should be independent experts. Whereas, in practice they submit to the same commanders and have to solve problems of interrelations with them. In this respect servicemen can rely only on themselves not wishing to get advice from unqualified personnel.

\section{Concluding comments}

The research has allowed us to get a ranging of servicemen's social problems: housing, material maintenance and hard-earned money, realization of social guarantees, life conditions and problem of relationships within families, time-limit, the regulation of life, restricting the freedom, humiliating treatment of juniors and bullying.

Provision of housing for the servicemen is carried out through actions of such programs as "State Housing Certificate", "Accumulation System of Buying Accommodation", and also distribution of service housing from resources of the Ministry of Defence. Directly the solving of the housing problem are connected with the life conditions and problem of relationships within families, because servicemen accommodation in the terrible conditions for lives. Duties of the social worker under this point include servicemen family living and housing survey, an explanation of rights and duties to servicemen in the field of the housing law, the help in the registration for accommodation, control over timely allocation of apartments or rooms in a hostel for the servicemen.

One of leading point is occupied with a problem of material maintenance of servicemen. It can provoke neglectful attitude to duties and even illegal actions of servicemen. Despite of the fact that the salary of servicemen directly isn't connected with military social work, however the social worker can submit an initiative offer with in governmental bodies, proving necessity of increase 
in the average level of servicemen life. Besides, the military social worker can survey families and react to the problem situations, involving various experts if conflict level in families is high.

The third point is the insufficient maintenance with social guarantees. It is directly connected with activity of military social workers as actual ombudsperson. Low legal knowledge of servicemen is a serious problem in the field of realization their rights and guarantees. In this case the social worker should conduct activity on knowledge of servicemen, act as their advocate at infringement of the rights and not granting some benefits from Command of the military unit.

The rigid time-limit regulation freedom life excites basically common soldiers, sergeant and junior command personnel that is obvious because they often enter into the army environment with psychologically and physically unprepared to this regulations. In this case the social worker together with the psychologist can spend behavioural training on assembly points of the Recruitment office and at the military institutes, creating positive installation on a forthcoming regulations, preparing for certain rules and conditions of the military organization.

Humiliating treatment of juniors as the social phenomenon has already strongly taken roots in the Russian army. Principally it excites junior enlisted, because the officers, as a rule, try to ignore the facts of the harassment. Moreover, humiliating treatment of juniors is attributed positive characteristics because it is a control system which also can be supervised. In these context social worker duties include support of junior enlisted and performance of certain educational actions as in Russian tradition. Besides, social workers analyze discipline in the military units and submit an initiative offer with in command of military formations on prevention of possible crime and the facts of harassment.

Inconsistency of military reform and critical condition of Russian economy form a marginal layer of servicemen with a complex of psychological, economical, legal and social problems. Such problems ask for immediate solution. Social protection in the context of social policy presupposes overcoming social inequality, practices of social exception of military men and placing such category of citizens within the status group of "middle class".

It is of great importance to pay more attention to the activities of military social worker who has to use various models and techniques in order to help servicemen in their social adaptation to the army and post army society. One of such methods that combines elements of all models is focusing on the study of "life and experience". Analysis of servicemen life can be used in combination with any other model of social work. It can be very positive and increase efficiency of socialpsychological support to this category of people. It is important to organize group and individual work on rendering social-psychological help to conscript personnel, regular soldiers, and military men under contract. Social worker can develop programs of social-psychological adaptation for military personnel, former servicemen, women in the military. Activities of social workers should be directed to assist such categories of citizens whose rights are violated. In this connection, job position of military social worker is of great importance in all military units.

\section{References}

- Bannikov, K. (2002) Anthropology of extreme groups: dominant relations among servicemen of involuntary service of the Russian Army M.: "Nauka", 2002;

- Daley, J.D. (2003) Military social work. A multi-country comparison // International Social Work, 46(4). P. 437-448;

- Daley, J.G. (1999) Social work practice in the military. Binghamton, NY: Haworth Press;

- Flynn, M. \& Hassan A. (2010) Unique challenges of war in Iraq and Afganistan. // Journal of Social Work Education, March 22, 2010 
- Garber, D.L. \& McNeilis, P.J. (1995). Military social work. // Encyclopaedia of Social Work (19 $9^{\text {th }}$ ed., pp. 17261736). Washington, DC: NASW Press. // In Simmons, C.A. \& Rycraft, J.R. (2010) Ethical challenges of military social workers serving in a combat zone // Social Work, Volume 55, Number 1, January 2010 , P. 9-18

- Grigorieva, I. Social Policy: the Main Concepts. //The Journal of social policy studies. Volume 1, №1. P. 29-44;

- Kashchenko, E.A. (2003) Sexual Culture of Servicemen. M.: Editorial URSS

- Kennedy, D. (1999) The future of navy social work. // In Tallant, S.H. \& Ryberg, R.A. (2000) Social Work in the Military: Ethical Dilemmas and Training Implications // http://isme.tamu.edu/JSCOPE00/Tallant00.html

- Lipski, I. (1998) Military social work at the level of person. // Army and a society. №1. P.84-95

- Lugovaya, O.M. (2004) Pedagogical conditions of professional readiness' formation of experts on social work with military men and members of their families. Stavropol'

- Luk'yanec, A.A., Simonnkov, S.J., Sinkevich, J.S., Turin, A.I. (2005) Reference book of the army psychologist, officer for organization of public-state training and military-social work. M.: For the servicemen rights;

- McNelis, Peter J. (1993) Servicemen and Social Work // Encyclopaedia of Social Work // Editor-in-Chif Anne Minahan. M: Centre of the Universal Values. Volume 1. - P.117-122;

- Moller, B. (2000) The Concept of Security: The Pros and Cons of Expansion and Contraction. COPRI Working Paper, №26, P.1-25;

- Mukhin, V. \& Baranov, N. (2003) Housing Problems in the Army is still acute // Independent Military Review. № 37 (361). 10.11. 2003;

- Muthien, B. (2000). Women's Security is Human Security: Southern African Dimensions //http://www. human.mie-u.ac.jp/ peace /ipra_papers /muthien-genderedsecurity.doc;

- Order of Minister of Defense of the Russian Federation № 226 «About bodies of educational work in the Armed forces of the Russian Federation» of 06.07.1995

- Pechenkin, V., Bagutskij, N. \& Surkova, I. (2008) Quantitative of research in marketing, advertizing, social work and anthropology. A stage of statistical data's preparation - Saratov: Publishing house Saratov state technical University;

- Peven, L.V. \& Shishknov, A.I. (2002) The State and perspectives of solving social problems of servicemen //Sociological Research, №5;

- Romanov, P. \& Gatvinski, A. (2003) Social Changes and Social Policy. // The Journal of social policy studies. Volume 1, №1. P. 45-67

- Serebryannicov, V. (2002) From militancy to peacefulness // Sociological researches, №5;

- Simmons, C.A. \& DeCoster, V. (2007) Military social workers at war: their experiences and the educational content that helped them //Journal of Social Work Education, September 22, 2007;

- Simmons, C.A. \& Rycraft, J.R. (2010) Ethical challenges of military social workers serving in a combat zone // Social Work, Volume 55, Number 1, January 2010, P. 9-18

- Sorokin, P.A. (1992) Social stratification and mobility: Man. Civilization. Society // Edited by Sogamonov A.Y., M.: Politizdat;

- Surkova, I. (2006) Social policy in the army: gender context. Saratov: Scientific book;

- Tallant, S.H. \& Ryberg, R.A. (2000) Social Work in the Military: Ethical Dilemmas and Training Implications // http://isme.tamu.edu/JSCOPE00/Tallant00.html;

- Tarpley, A. (1999) The future of air force social work. // In Tallant S.H. \& Ryberg R.A. (2000) Social Work in the Military: Ethical Dilemmas and Training Implications // http://isme.tamu.edu/JSCOPE00/Tallant00.html

- The Federal Law N 76 "About the Status of Servicemen" 27.05.1998 (edition 22.07.2010)

- Tompson, D.L. \& Priestley, D., (1998) Sociology. M:"Publishing house AST", 1998;

- Yarskaia, V.N. Social policy, welfare State and Social Management: Issues of Analusis. //The Journal of social policy studies. Volume 1, №1. P. 11-28;

(2003) Social Aspects of the Military Reform // http://www.nasledie.ru/voenpol/ 14_14/article. php?art=18;

(2007) In the Russian army the quantity of service-women has twice increased over the last 10 years // http://www.newsru.ru/russia/ 06mar2007/ army_woman.html. 6.03.2007 (2009) NYT: servicemen are left to the whim of fate because of reductions in the Russian army // http://www.newsru.com/russia/12jun2009/army.html. 12.06.2009

(1999) Army of Russia: Its state and perspectives / Edited by Yanovsky R.G., Derugin Y.I., M: ISPI RAN; (2005) 3,000 Russian recruits die of army hazing every year // http://english.pravda.ni/ accidents/21/96/383/15005_hazing.html; 